\title{
AC 2010-763: DESIGN OF EXPERIMENT AND PROJECT MANAGEMENT METHODOLOGIES SUPPORT A SENIOR PROJECT RESEARCH COURSE AND ITS ASSESSMENT
}

\section{Peter Baumann, Central Connecticut State University}

Dr. Baumann is an Associate Professor of Engineering at CCSU. His industrial experience spans 20 years. He is Past Chairman of American Society for Testing and Materials (ASTM) Committee B7 and is on his local ASM International chapter's Board of Directors. Dr. Baumann received a B.S. in Metallurgy at Penn State, earned an M.S. from MIT Mechanical Engineering, and completed a Ph.D. in Materials Science at Polytechnic University. E-mail:

BaumannP@ccsu.edu

\section{Nidal Al-Masoud, Central Connecticut State University}

Dr. Al-Masoud, Associate Professor, earned his Ph.D. in Mechanical Engineering from The University at Buffalo, The State University of New York in 2002. Dr. Al-Masoud has taught at both graduate and undergraduate level courses at University at Buffalo, he joined Central Connecticut State University as an Assistant Professor in 2003. At CCSU, he teaches courses at all levels in the three major areas in mechanical engineering, namely: mechanics, Thermo-fluid, and Control Systems and Dynamics. Dr. Al-Masoud research interests are in the fields of Control Systems and Dynamics, HVAC systems, and Engineering Education. He has numerous journal and conference proceeding publications in the aforementioned area, and was the winner of the ASEE Mechanics Division Best paper Award in 2006. He has an extensive experience in Heating Ventilation and Air Conditioning Systems (HVAC) design. Dr. Al-Masoud is very active in many Professional Societies. He serves on the Board of Directors of American Society of Mechanical Engineers, Hartford Section; he is also the Faculty advisor of CCSU-ASME Student section. He is a member of the American Institute of Astronauts and Astronautics (AIAA), IEEE, ASEE. 


\title{
Design of Experiment and Project Management Methodologies Support a Senior Project Research Course and Its Assessment
}

\begin{abstract}
Motivated by required program learning outcomes and recommendations from a continuous improvement plan focus group, Central Connecticut State University has uniquely organized its mechanical engineering senior project design research class to include significant review of Design of Experiments (DOE) and Project Management (PM) methodologies. Both studies have been linked to computational software tools for students to use in their capstone experience. The ultimate goal of the class is a project design proposal in which researched background information forms the introduction to a managed project plan which can include designed experimentation within the statement of work. This course organization has been found to be both beneficial for student capstone progress and integral to our accreditation efforts, through examinations and reports and their subsequent assessment.
\end{abstract}

\section{Introduction}

According to Schuster, Davol and Mello at California Polytechnic State University, one of the best ways to engage students is through design activities. They comment on the many popular intercollegiate design competitions which provide motivation to students and list Formula SAE, SAE Mini Baja, and ASME Human Powered Vehicle from their own experiences. It is their contention that "The experience of going through the design, build, and test cycle under a strict time schedule with well defined goals gives these students more of a 'real world' engineering experience than they get through their standard course work." They add that many schools tackle these projects within senior design classes. Their work acknowledges the constraint of development time to be particularly troubling within the management of these projects. They also cited risks associated with a "build-and-test" approach. ${ }^{1}$

At Virginia Tech, Pierrakos, Borrego and Lo assess EAC of ABET mechanical engineering program learning outcomes through their senior capstone design experience. They have used Bloom's taxonomy competencies of (1) knowledge, (2) comprehension, (3) application, (4) analysis, (5) synthesis, and (6) evaluation, to establish cognitive skill level, in addition to their student learning outcomes assessment. A thorough grouping of numerous personal/professional and technical learning outcomes are assessed, and they have observed that the outcome of designing and conducting of experiments is one of the lowest rated. Among outcomes tied to management of the project, "follow a budget" was also rated low. ${ }^{2}$

In a paper titled "Competency-Based Engineering Design Projects," Davis et al. of Washington State University describe the strategic planning of project assignments in team-based design projects as key to achieving design competence. Through the framework of an assignment handout, six important elements are noted: Title, Abstract, Objectives, Tasks (steps), Product expected, and Resources and constraints; the latter three are integral to project management focus on scope, time and cost. Also included in their work are design steps for identifying specific parameters together with the planning and conducting of experiments. ${ }^{3}$ 
Felder and Brent of North Carolina State University, in their paper "Designing and Teaching Courses to Satisfy the ABET Engineering Criteria," provide ideas for problem-based learning methods to address all outcomes. Specifically, for experimentation, they suggest that, "Rather than having student teams work through a large number of pre-designed experiments ... have the student teams devise and implement experiments to solve them." They continue their recommendation for faculty to "Provide instruction or resources for self-study in experimental design, statistical data analysis ... only after the teams have encountered a need to know the material." 4

Many universities have integrated project management into their curricula to varying degrees, from individual PM courses ${ }^{5,6}$ and coursework ${ }^{7}$ to its inclusion within senior capstone design projects. $^{1,8,9}$ Design of Experiments is often found to be included within laboratory-based and experimentation courses ${ }^{10,11,12,13,14}$ and only some had DOE involved with the capstone design course. $^{15,16}$ Some of these efforts, however, did not institute formal training of traditional DOE methodologies and designs.

In its newly developed mechanical engineering program, CCSU has a two-term senior project capstone course requirement. These student projects may originate from the student, instructor, and/or industrial partner. Senior Project I (ME 497), a research class, prefaces and is intended to prepare students for Senior Project II (ME 498), the final capstone design project course. The former of these courses, the focus of this paper, has not only provided adequate introduction for senior project design but has been uniquely organized to achieve several program learning outcomes. This course organization, which includes both DOE and PM principles to support the capstone design effort, that are derived via accreditation requirements and internal continuous improvement activities, has proven to be an integral and valuable part of our curriculum. The effort found most closely resembling ours is that of Stone and Hubing ${ }^{16}$ at the University of Missouri-Rolla (now Missouri University of Science and Technology) which has aspects of both project management and design of experiments; within the context of their overall engineering design methodology course, however, these were limited in comparison to the emphasis at CCSU.

In our overall program assessment plan, computerized exams are used to judge student ability to use software tools learned in support of engineering concepts and practices. An example of this assessment occurs in the program's senior project research class, ME 497. In this course, students prepare the general project design proposal, performing literature research and review, which lead to the project work plan or statement of work for future implementation. Our proposal outline contains all of those elements suggested by Davis et al. ${ }^{3}$, as well as a review of available literature in order to establish the background for the design activity. To support the possibility of experimental research, Design of Experiments (DOE) is introduced using the inhouse Minitab® software package. Additionally, Project Management (PM) methodologies and the Microsoft $®$ Office Project tool are developed to assist in the project planning phase. The use of this software for project management is echoed by Porter, Morgan, and Zoghi ${ }^{9}$ at Texas A\&M University. 


\section{Design of Experiments (DOE) Inclusion}

According to the current ABET Criteria for Accrediting Engineering Programs, all engineering programs must demonstrate that graduating students have "an ability to design and conduct experiments, as well as to analyze and interpret data." As a prelude to potential project experimentation or testing of project designs, students within our capstone research class are introduced to several useful classes of experimental designs. Design of Experiments (DOE or DOX) can actually invoke or is often depicted as a stepwise methodology or strategy as charted by Del Vecchio and presented as Figure 1. Often in a team approach to design or experimentation, team members contribute via brainstorming of potential factors which will influence the final design or results. If the factors are too numerous, students are exposed to several factor screening designs and techniques to limit the number of factors and their overall investigation. Traditional factorial (or interaction model) designs are used in turn, followed by the potential for optimization through response surface methodology. ${ }^{17,18}$

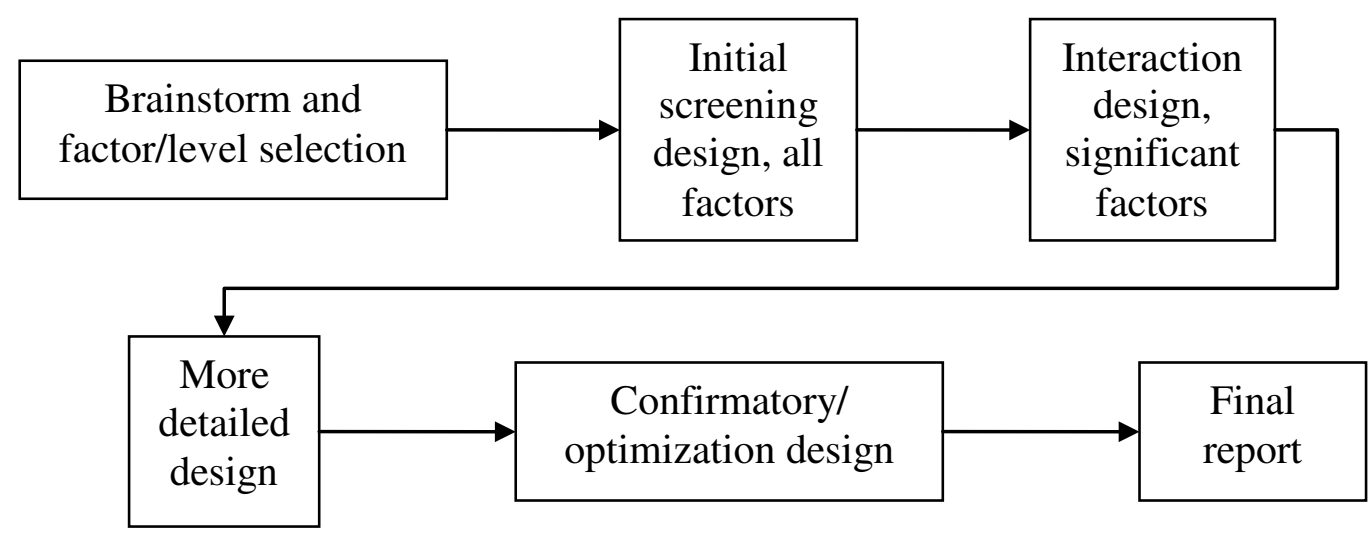

Figure 1. Simplified flow diagram for a project using designed experiments. ${ }^{18}$

Initially, the students' developed backgrounds in statistics, probability theory, and regression analysis are expanded through review of baseline factorial experimentation. Text examples of designed experiments with obtained results facilitate student learning. Within the Minitab® environment, these experimental designs are created, randomized, and the experimental results analyzed. Using statistical analysis software, students establish factor effects, perform statistical analysis of variance (ANOVA) to isolate significant factors and interactions, derive associated regression equations (including linear, interaction, and full-quadratic), validate the statistical assumptions for residuals, and graphically portray and interpret the results. Partial factorials, including Plackett-Burman, are introduced as potential screening designs. Students readily learn that these can limit the number of factors in those cases in which a multitude may potentially influence results. Ultimately, response surface designs can provide more detailed or complex models used for result optimization, together with the factor levels or operating conditions needed to achieve these desired results. ${ }^{19,20}$ Examination of students, through a locally generated computerized exam, with subsequent assessment has provided immediate outcome demonstration. The results are referenced to a 4-point attainment level metric used throughout 
our program assessment process, with scale presented in Table 1. ${ }^{21,22}$ Charted data of measured assessments from fall 2008 and spring 2009 are shown as Figure 2.

Table 1. Outcome Assessment Rating Scale

\begin{tabular}{|c|l|}
\hline Rating & \multicolumn{1}{|c|}{ Commentary } \\
\hline 1 & Not Fulfilled (not attained) \\
\hline 2 & Attained (70\% minimal) \\
\hline 3 & Meets (80\% fulfilled) \\
\hline 4 & Exceeds (90\% fulfilled) \\
\hline
\end{tabular}

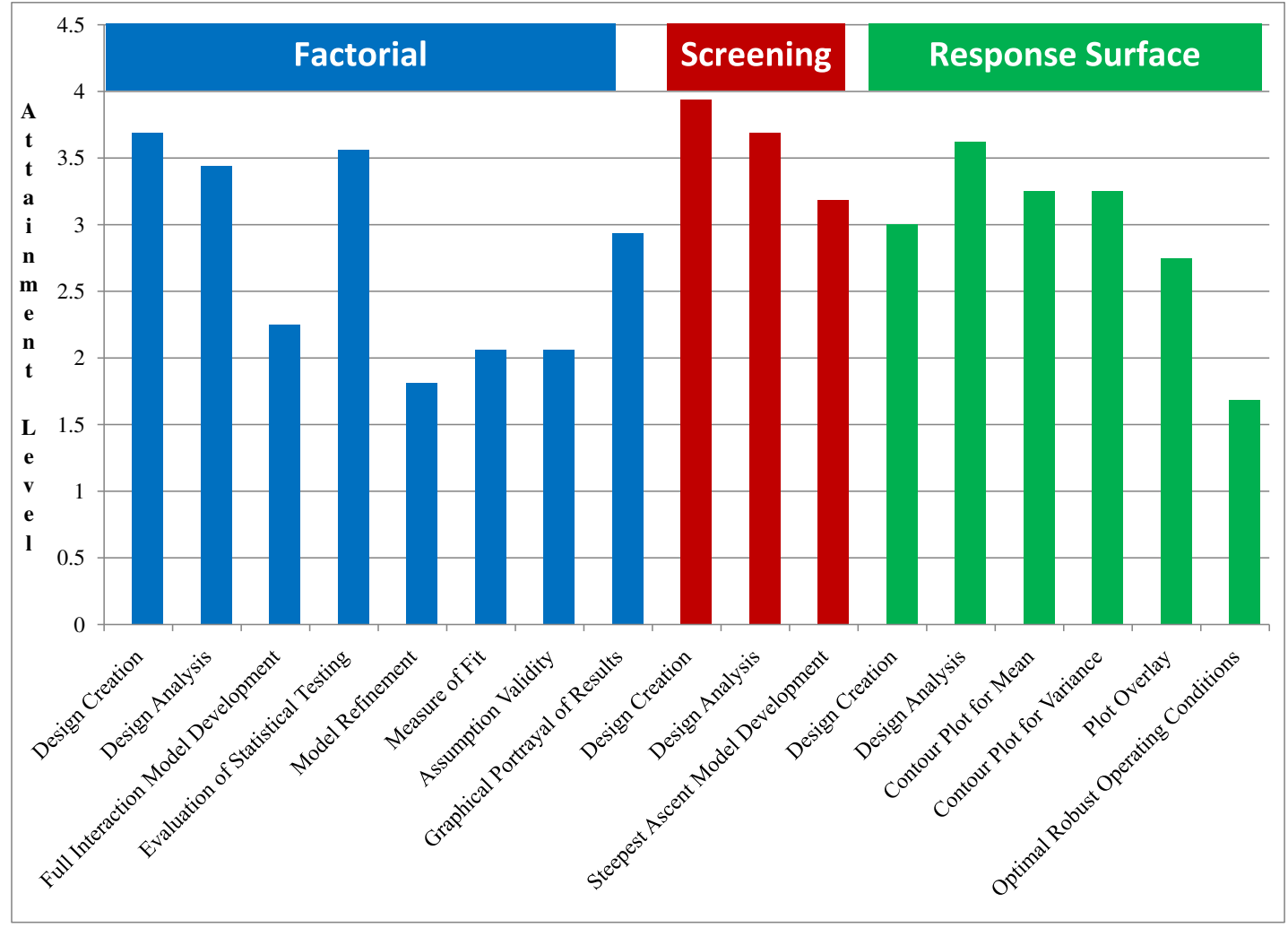

Figure 2. Design of Experiments (DOE) assessment averages for fall 2008 - spring 2009.

Currently, within our continuous improvement plan, any attainment level rating less than 2 is cause for concern, and if prolonged must be remedied. Review of these indicators reveals a need for improving student ability to properly refine the model equation and establish optimum design (or operating) conditions. 


\section{Project Management Integration}

At its fall 2007 meeting, the CCSU Mechanical Engineering Industrial Advisory Board (IAB) recommended that students be exposed to project planning, specifically, the managerial aspects of engineering projects covering finance, quality, and scheduling. This desire aligns well with the general project management view of projects in terms of time, cost and scope, and their interdependencies. ${ }^{23}$ For a particular project scope: if duration must be reduced, costs must increase; if costs must be reduced, duration must increase. Also, for an increased project scope one must increase duration or cost or both; with decreased scope one may decrease duration or cost or both. Responding to these focus group recommendations for project management skills, the faculty decided to include this topic in ME 497, Senior Project I: Project Research. Students are introduced to project management tools and software and learn to perform many skills.

Initially, students start work within the Microsoft $₫$ Office Project environment by reviewing the various views for a single canned project available within the software package. The default Gantt Chart view is complemented by the Resource Sheet, Task Sheet, Resource and Task Usage Sheets, the Calendar, and Network Diagram (flowchart), to name a few. These views can clearly indicate to students some aspects of a good project management system such as the tasks to be performed, the order of task performance, the timing of tasks, the task assignments, costs associated with using the resources, and the adequate communication of project details. This introductory review is then supplemented by the creation of a new project plan via naming, start date establishment, and the setting up of non-working time through the use of a general base calendar and introduction of exceptions.

Creation of task lists is the next phase of the pedagogical effort. Tasks, the basic building blocks, are all described by sequence, duration and resource assignments. Tasks are organized under summary tasks or headings and linked to establish the timing relationships, i.e., the order of precedence. Also introduced are the special milestone task used for significant events and deadlines, as well as the ability to provide extra notation through the use of task notes on the task sheet portion of the Gantt Chart.

Effective resource management is critical to successful projects. Students establish all three types of resources: work (people and equipment), material (consumables), and cost (other task costs), noting that all resource usage impacts project cost but only work resources affect scheduling. Pay and usage rates, as well as percent of work resource availability, are entered on the Resource Sheet. Assignments are then made by the matching of one or more resources to a task; this establishes the work effort through the scheduling formula, that is, duration multiplied by percent availability equals the work effort. At this point students are cautioned to exercise care when adding resources to tasks due to the effort-driven scheduling, i.e., once the initial assignments are made, work is constant, so adding people now reduces time, unless the scheduling function is turned off.

Last is the project management tracking phase. In tracking, actuals are recorded such as partial project completion, task partial completion or finishing, materials consumed, and specific costs incurred. Following project baseline establishment, students track either updated work complete through a particular date, task completion percentages or actual start, finish and duration values 
for a task. Ultimately, students are shown various means to format or customize their plans, as well as being given a review of the wide array of Microsoft ${ }^{\circledR}$ Office Project canned and customizable reports appropriate to the various project stakeholders.

Throughout all these phases, the student design project teams are asked to reinforce classroom briefings by applying them to their own proposed senior design project plan. The resulting project plan may then be presented within the statement of work of the project design proposal.

At the end, students are presented with a project scenario on an in-class computerized exam for which they are required to create task and resource lists, schedule work order, assign resources, track progress, and report on project completion and associated costs. Each of these and some additional elements are graded and assessed following the exam. The results for several offerings are shown below in Figure 3. Again assessment of this mock project exam has provided demonstration of student abilities for several outcomes.

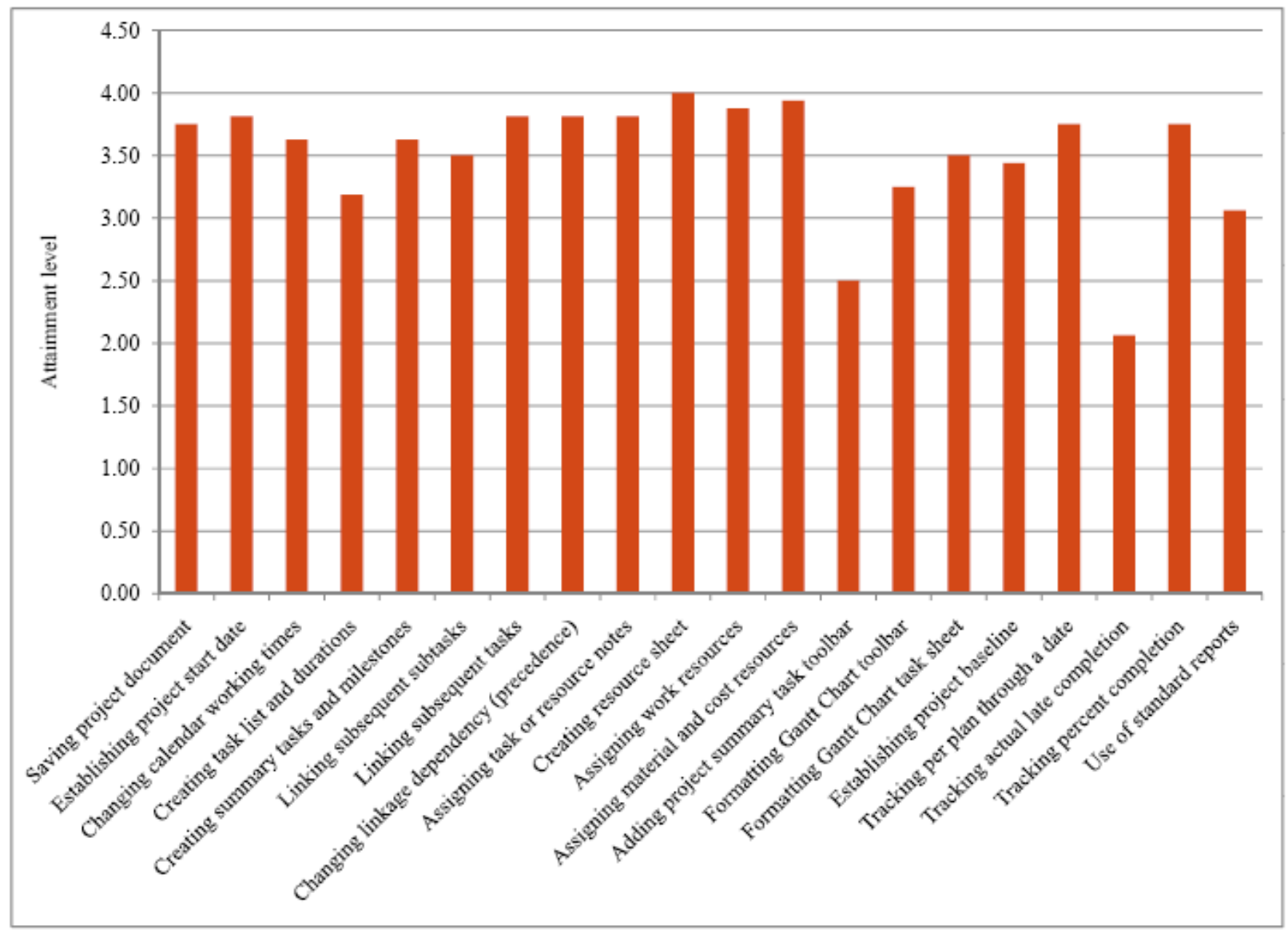

Figure 3. Project management assessment averages for ME 497 2008-2009. 


\section{Resulting Project Design Proposal}

The ultimate goal of our research class is the development of the project design proposal. Students are provided an outline for the expected elements in their final senior design project reports. These elements are typical for a formal report including: Title Page, Acknowledgements (if desired), Abstract, Table of Contents, List of Figures, List of Tables, Nomenclature (for heavy use of symbols or acronyms), Introduction, Statement of Work, Results, Discussion, Conclusion, Bibliography, and Appendices. The required project design proposal includes all of these items, as complete as possible, sans Results, Discussion, and Conclusion sections, which will be added later during the follow-up ME 498 Senior Project Design (Capstone) course. To this end, researched background information from reputable sources augments website data gathering to provide the project report introduction; this is coupled with the managed project plan, often including designed experimentation, within the statement of work.

The connections to our goals are apparent and the written proposal with oral presentation provides additional assessment opportunities. All student teams are required to apply PM practices to their planned capstone project, which usually includes Microsoft ${ }^{\circledR}$ Office Project output within the final oral and written reports of the project proposal. Having these detailed and modifiable plans should definitely improve the quality of student projects in the second semester; evidence in support of this assertion has not yet been collected. Although many students pursue projects that are not necessarily experimental, they are encouraged to consider designed experimentation efforts for design optimization and validation. Such efforts could avoid the risks acknowledged by Schuster et al. ${ }^{1}$ with the build-and-test approach by proposing the corollary of test-and-build.

\section{Discussion}

Upon review of the literature concerning engineering assessment and student design projects, two papers ${ }^{24,25}$ purported to have developed entrepreneurial skills in engineering students. Specifically, Ports ${ }^{25}$ of Florida Institute of Technology states, "there is a growing interest in linking Senior Design with entrepreneurial activities, even to the point of commercializing promising project results." He claims that they have structured their capstone sequence (which includes project management) toward a start-up venture goal and have greatly increased the number of design teams desiring to market. Related to this, Pierrakos et al. ${ }^{2}$ commented on design benchmarking, including a review of information provided by the U.S. Patent and Trademark Office, as standard research. Since we at CCSU have also had projects of such potential (several in patenting phase), we believe that this kind of inclusion would be beneficial for our students and are grateful to consider the entrepreneurial addition as future development work within the research class.

\section{Conclusions}

The capstone research course organization with significant Design of Experiment and Project Management components, developed through accreditation requirements and internal continuous improvement plans, was found to have been beneficial for both accreditation efforts and students, and we invite others to follow suit. Such organization can also support other program 
learning outcomes, such as the use of modern engineering tools, life-long learning, and preparation for graduate study, and we have made these connections in previous referenced ASEE papers.

Upon completion of this course, sufficient progress has been realized and students have been very gratified that they are well along (approximately halfway) in their Senior Design Project Capstone.

The effect of this course and the overall capstone experience will definitely extend beyond fulfilling the Program Learning Outcomes. Competencies such as project management, the ability to seek and analyze alternative solutions for multidisciplinary open-ended design problems, and team work are indispensible ingredients of a successful career in engineering, thus fulfilling some of the program educational objectives.

\section{Bibliography}

1. Schuster, P., Davol, A. and J. Mello, "Student Competitions - The Benefits and Challenges," Proceedings, 2006 ASEE Annual Conference (Washington, DC: American Society for Engineering Education, 2006).

2. Pierrakos, O., Borrego, M. and J. Lo, "Assessing Learning Outcomes of Senior Mechanical Engineers in a Capstone Design Experience," Proceedings, 2007 ASEE Annual Conference (Washington, DC: American Society for Engineering Education, 2007).

3. Davis, D. C., Crain Jr., R. W., Calkins, D. E., Gentili, K. L., and M. S. Trevisan, "Competency-Based Engineering Design Projects," Proceedings, 1996 ASEE Annual Conference (Washington, DC: American Society for Engineering Education, 1996).

4. Felder, R. M. and R. Brent, "Designing and Teaching Courses to Satisfy the ABET Engineering Criteria," Journal of Engineering Education, January 2003, pp. 7-25.

5. Cottrell, D. S., "Integrating Construction Engineering Planning Into a Structural Civil Engineering Program," Proceedings, 2000 ASEE Annual Conference (Washington, DC: American Society for Engineering Education, 2000).

6. Rad, F., Huff, S., Mohammadi, A., McCormack, T. and D. Richwine, "Our Experience with Guiding a Major Design Experience in Civil Engineering Curriculum," Proceedings, 2001 ASEE Annual Conference (Washington, DC: American Society for Engineering Education, 2001).

7. Sepahpour, B., and N. L. Asper, "A Promising Model for Integrating Design in Undergraduate Engineering Curriculum," Proceedings, 2001 ASEE Annual Conference (Washington, DC: American Society for Engineering Education, 2001).

8. Byam, B. P., "An Enhanced Educational Experience for Capstone Design Projects: Using SAE Student Groups in An Industry Sponsor Role," Proceedings, 2002 ASEE Annual Conference (Washington, DC: American Society for Engineering Education, 2002).

9. Porter, J. R., Morgan, J. A. and B. Zoghi, "Integrating Project Management into the Capstone Senior Design Course," Proceedings, 2002 ASEE Annual Conference (Washington, DC: American Society for Engineering Education, 2002).

10. Lyons, J., Young, E. F. and J. Morehouse, "Capstone Mechanical Engineering Laboratory Uses Racecar," Proceedings, 2000 ASEE Annual Conference (Washington, DC: American Society for Engineering Education, 2000).

11. Lyons, J. S., Morehouse, J. H. and E. F. Young, "Design of a Laboratory to Teach Design of Experiments," Proceedings, 1999 ASEE Annual Conference (Washington, DC: American Society for Engineering Education, 1999).

12. Schmaltz, K., Byrne, C., Choate, R. and J. Lenoir, "Senior ME Capstone Laboratory Course," Proceedings, 2005 ASEE Annual Conference (Washington, DC: American Society for Engineering Education, 2005). 
13. Robinson, R. J., "Improving Design of Experiment Skills through a Project Based Fluids Laboratory," Proceedings, 2002 ASEE Annual Conference (Washington, DC: American Society for Engineering Education, 2002).

14. Litwhiler, D. W. and M. J. Kiemele, "TQM and DOE in an Undergraduate Curriculum: Success Stories," Journal of Engineering Education, April 1994, pp. 147-151.

15. Sheybani, E., Garci-Otero, S. and K. Williamson, "Implementing ABET Engineering Criteria 2000 for New Programs at a Small HBCU," Proceedings, 2009 ASEE Annual Conference (Washington, DC: American Society for Engineering Education, 2009).

16. Stone, R. B. and N. Hubing, "Striking a Balance: Bringing Engineering Disciplines Together for a Senior Design Sequence," Proceedings, 2002 ASEE Annual Conference (Washington, DC: American Society for Engineering Education, 2002).

17. ABET. 2009-2010 Criterion for Accreditating Engineering Programs. (Baltimore, MD: Accreditation Board of Engineering and Technology, 2009).

18. Del Vecchio, R. J. Understanding Design of Experiments: A Primer for Technologists. (Cincinnati, OH: Hanser/Gardner Publications, 1997) pp. 77-82.

19. Minitab. Meet Minitab 15 for Windows ${ }^{\circledR}$, (State College, PA: Minitab Inc., 2006).

20. Montgomery, D. C. Design and Analysis of Experiments, $7^{\text {th }}$ Ed. (Hoboken, NJ: John Wiley \& Sons, Inc., 2009).

21. Al-Masoud, N., Baumann, P. F. and A. Gates, "Development and Implementation of an Integrated Outcomes-Based Assessment Plan for a New Engineering Program," Proceedings, 2009 ASEE Annual Conference (Washington, DC: American Society for Engineering Education, 2009).

22. Lema, L. F., Baumann, P. F. and Z. Prusak, "In-common Methodology for Objective- and Outcome-based Programs Assessment," Proceedings, 2005 ASEE Annual Conference (Washington, DC: American Society for Engineering Education, 2005).

23. Chatfield, C. and T. Johnson. Microsoft ${ }^{\circ}$ Office Project 2007 Step by Step. (Redmond,WA: Microsoft Press, 2007).

24. McGourty, J., Reynolds, J., Besterrfield-Sacre, M., Shuman, L. and H. Wolfe, "Using Multisource Assessment and Feedback Processes to Develop Entrepreneurial Skills in Engineering Students," Proceedings, 2003 ASEE Annual Conference (Washington, DC: American Society for Engineering Education, 2003).

25. Ports, K., "Structuring Senior Design for Entrepreneurs," Proceedings, 2005 ASEE Annual Conference (Washington, DC: American Society for Engineering Education, 2005). 